\title{
Development of Integrated Physics Learning E-Module with Pancasila Character Values in Work and Energy Subjects
}

\author{
Aprilia Mayang Sari ${ }^{1, *}$ Ariswan $^{1}$ \\ ${ }^{I}$ Physics Education, Graduate School, Universitas Negeri Yogyakarta, Sleman, Indonesia \\ "Corresponding author.Email: apriliamayang.2018@student.uny.ac.id
}

\begin{abstract}
This study aims to produce an integrated physics learning e-module with Pancasila character values in work and energy subjects that is feasible to use. The type of research used is research and development. The development procedure is guided by the 4-D model. Research subjects consisted of material experts, media experts, physics teachers, peer reviewers, and 30 students of class X MIPA SMA N 1 Gading Rejo. The data collection technique used observation techniques, literature study techniques, documentation, and questionnaire techniques. The research instruments used include observation sheets, product feasibility assessment sheets, and student response questionnaire. Data collected were analyzed using descriptive analysis. The results showed that the integrated physics learning e-module with Pancasila character values in work and energy subjects was feasible for use with the "Very Good" category based on the assessment of material experts, media experts, physics teachers, peer reviewers, and student responses. Based on these findings, the teacher can use this e-module as a reference for student learning resources in the learning process both inside and outside the classroom because the e-module has been tested for its feasibility.
\end{abstract}

Keywords: Physics Learning E-Module, Pancasila Character Values, Work and Energy.

\section{INTRODUCTION}

The implementation of education in Indonesia and even throughout the world today is faced with the development and rapid technological progress [1]. The development and advancement of technology now allow anyone to learn anytime and anywhere with a very broad scope, for example by e-mail, chat, e-book, e-library, and even allows everyone to share information sans having to meet in person with the source of the information [2]. Because of all the information we want can be obtained only by accessing the internet. The development of increasingly advanced technology, also allows educational institutions to utilize multimedia facilities in learning [3]. The learning process can be realized through modules that are more interactive and attractive to learners, for example using flash, an explanation through voice/audio media, and the addition of features that can increase active student participation [4]. This very rapid technological development indicates a change in an increasingly modern world, especially in the era of globalization [5]. Globalization has triggered a shift in the world of education from conventional face-to-face gatherings to more open education. Education in the future will be supple, open, and reachable to anybody who requires regardless of age, or prior educational experience [6]. Education in the future will be more decided by information networks that enable collaboration and interaction, not oriented to class buildings [7]. Trends in innovation and transformation in the world of education will keep on to happen and expand in entering the 21st-century nowadays. These transformations among others a simplicity finding of learning resources, more choices for exerting ICT, improving the role of media, and multi-media in activities of learning [8]. But what is important to remember is the existence of these changes, requiring each individual to be able to adapt to the progress of life that is increasingly modern, have the ability/ skills in order to live and contend in the future [9]. 
In addition to these positive impacts, it turns out that technological developments and advances that are very rapid can also cause various negative impacts. Especially if not used properly [10]. Various negative impacts that may be caused, among others, the use of e-learning can cause the transfer of teachers and cause the teacher to be excluded, causing the creation of individuals who are individual, ethics and discipline of students difficult to supervise and foster, so that gradually and ethics and humans, especially students will decrease dramatically, the nature of humans as social beings will be eroded [11]. Other impacts that may be caused include students not really accessing things that are not good, such as pornography, online games can even be exposed to cyber-relational addiction. Students become addicted to excessive cyberspace existence, being exposed to or committing criminal acts (cybercrime), causing apathy towards each individual, and so on [12],[13]. Things like rampant student fighting, cheating on national exams, drug cases that ensnare students, pornographic videos by students, sexual harassment, moral degradation, and even now are becoming problems faced by the education world [14],[15].

Responding to the various positive and negative impacts, education, in addition, must always and constantly adjust technological developments to means to increase the education quality, it must also be able to shape humans who have superior skills and character in order to be capable to contend and live in the future [16]. This is conformable towards Law No. 20 of 2003 concerning the National Education System which states that national education functions to develop capabilities and shape the character and civilization of a dignified nation in the context of educating the life of the nation, aiming at developing the potential of students to become human beings of faith and devotion to God Almighty, noble, healthy, knowledgeable, capable, independent, and become citizens of a democratic and responsible. Based on the objectives and functions of national education, it is obvious that education in each degree, from basic education to higher education, should be systematically designed and organized to reach these objectives [17]. One of them which also needs to be prepared by educational institutions is facilities and infrastructures that support the achievement of these goals [14]. For example, educational institutions need to use media or learning resources that are integrated with character values [18]. Not only in subjects of religion and citizenship education but in all subjects [19]. But the media or learning resources used today, especially in physics are not fully integrated with character values. The sources used are only used as tools to convey knowledge but fully encourage the formation of character [20].

Based on various facts and problems, it is important to extend a learning resource that is integrated with character values. One learning source that can be chosen as an alternative is the e-module. The e-module was chosen because it has some material approved in electronic format, audio, animation, film, and navigation can be inserted which makes its use over interactive with the program [21]. It uses also provides benefits for students that can be used anywhere and at any time, and can be studied without depending on the teacher or others [22]. The presentation of material in e-modules can also be integrated with character values, one of which is sourced from Pancasila [23]. Pancasila was chosen because it is the philosophy and view of national life. Politics, economics, society, law, art, and even culture. This integration encourages students to become better citizens, namely citizens who have the will, ability, and implement the values of Pancasila in their lives [19]. The Pancasila character values that are integrated are values that are suitable to be integrated into the learning material. One of the materials in physics which is suitable to be integrated with the character values is work and energy materials. However, at present, there are no learning resources related to work and energy materials that are integrated with the Pancasila characters values. Therefore, this research tries to develop an integrated physics learning e-module with Pancasila character values in work and energy subjects.

\section{RESEARCH METHOD}

\subsection{Types of Research}

This research is research and development. The development procedure is guided by the 4-D model. This procedure consists of four stages namely define, design, develop, and disseminate. These stages are explained in more detail as follows.

\subsubsection{Define Stage}

This stage was carried out to determine and define various needs in the learning process. Furthermore, this is also helpful for gathering all kinds of information related to the product to be developed. This stage includes five steps, namely front-end analysis, student analysis, task analysis, concept analysis, and analysis of learning objectives. Front-end analysis and student analysis were carried out using observation and documentation techniques, while the analysis of tasks, concepts, and learning objectives was carried out using literature study techniques and documentation. The results at this stage are used as a basis for initial product development at the design stage.

\subsubsection{Design Stage}

This stage was carried out to obtain draft I of the initial design of the product being developed. This stage includes four steps, namely the preparation of tests, media selection, format selection, and initial product design. The initial design of the product begins with 
making a product development guideline, flowchart, and storyboard that is based on the results of the analysis at the define stage. The initial design of the product is then compiled based on guidelines, flowcharts, and storyboards that have been made. The result is an integrated physics learning e-module with Pancasila character values in work and energy subjects which will be continued at the development stage.

\subsubsection{Develop Stage}

This stage is carried out to get the product II draft. This draft is the result of revision based on input/ suggestions for improvement from experts, physics teachers, peer reviewers, and student responses. This stage includes two steps, namely validation/ assessment of product feasibility and product trials. Product feasibility assessment is carried out to determine product feasibility, input/ suggestions for improvement before the product is implemented in learning, or trialed. The assessment was conducted by a material expert, a media expert, three physics teachers, and three peer reviewers. After being repaired based on the validation results, the developed product is then trialed. A trial was conducted to obtain student responses to the product being developed. The trial was conducted on 30 students of class X SMA N 1 Gading Rejo.

\subsubsection{Disseminate Stages}

This stage is carried out to disseminate the results of the product so that it can benefit others. At this stage, the results of development are involved in seminars or published in scientific journals.

\subsection{Data Collection Techniques and Instruments.}

Data collection techniques used in this research were observation techniques, literature study techniques, documentation, and questionnaire techniques. Data collection instruments used in this research consisted of observation sheets, product feasibility assessment sheets for material experts, media experts, physics teachers, and peer reviewers, as well as student response questionnaires. The product feasibility assessment sheet contains two aspects of assessment, namely the material and media aspects with a total of five assessment components, namely content feasibility, language and images, presentation, graphics, and audio. The student response questionnaire contains six aspects of assessment, namely material, readability of language and image, presentation, module display, audio, and usage.

\subsection{Analysis data}

The data analysis technique used in this research is descriptive analysis. The results of the product feasibility assessment and student responses were analyzed by this analysis through the following stages.

- Tabulate all data that has been obtained.

- Calculate the average score on each aspect of the assessment using the Formula (1).

$\bar{X}=\frac{\sum X}{n}$

Information:

$\bar{X} \quad=$ average score

$\sum x=$ total score given by the evaluator in each aspect

$n \quad$ number of evaluator

- Comparing the mean score with the feasibility criteria index according to the standard scale that can be seen in Table 1 with a conversion scale of five that can be seen in Table 2 [24].

Table 1. Feasibility Assessment Criteria

\begin{tabular}{|c|c|}
\hline Range of Score & Category \\
\hline $\bar{X}>X_{i}+1.8 \mathrm{Sbi}$ & Very Good \\
\hline$X_{i}+0.6 \mathrm{Sbi}<\bar{X} \leq X_{i}+1.8 \mathrm{Sbi}$ & Good \\
\hline$X_{i}-0.6 \mathrm{Sbi}<\bar{X} \leq X_{i}+0.6 \mathrm{Sbi}$ & Enough Good \\
\hline$X_{i}-1.8 \mathrm{Sbi}<\bar{X} \leq X_{i}-0.6 \mathrm{Sbi}$ & Less \\
\hline $\bar{X} \leq X_{i}-1.8 \mathrm{Sbi}$ & Very Less \\
\hline
\end{tabular}

Information:

$\bar{X}=$ average score

$X_{i}=$ average ideal score $=\frac{1}{2}$ (maximum score + minimum score)

$S b i=$ ideal standard deviation $=\frac{1}{6}$ (maximum score minimum score)

Table 2. Feasibility Assessment Criteria

\begin{tabular}{|c|c|}
\hline Range of Score & Category \\
\hline $\bar{X}>3.4$ & Very Good \\
\hline $2.8<\bar{X} \leq 3.4$ & Good \\
\hline $2.2<\bar{X} \leq 2.8$ & Enough Good \\
\hline $1.6<\bar{X} \leq 2.2$ & Less \\
\hline $\bar{X} \leq 1.6$ & Very Less \\
\hline
\end{tabular}

Based on these criteria, if the average score of each aspect of the assessment is in the range $\bar{X}>3.4$ then it is in the very good category and if the average score is in the range of $2.8<\bar{X} \leq 3.4$ then it is in a good category. If every aspect is included in the good or very good category, then the product is declared feasible for use in learning.

\section{RESULTS AND DISCUSSION}

\subsection{Define Stage}

The results of the literature study carried out in this stage indicate several facts till problems. These facts and problems, including 1) the tendency of conditions of moral 
degradation, character, and ethics including related to student independence, 2) the low ability of students to complete their tasks, to handle themselves, to believe in themselves, to be able to regulate himself, answering questions, communicating with friends, etc. 3) Modules can also be integrated with character values to encourage students to develop their characters, but the modules used have not been able to fully develop student characters and have not been fully integrated with character values especially Pancasila character values, and 5) e-modules are still underused in learning.

This result is promoted with the observation results made at MAN 1 Yogyakarta on March 2019. Observation results show that 1) the learning that is done still tends to be teacher-centered, 2) the method used is the lecture method followed by the training of questions done by students on the board, 3) the presentation of the material is done without media or other learning resources but served with the help summary of the material that has been delivered by the teacher before, 4) students rely on the aid of other students to work the task or answer teacher questions, 5) student behavior shows a lack of interest in learning physics, and 6) there are no physics learning resources that integrate Pancasila character values.

These facts and problems form the basis for the development of an integrated physics learning e-module with Pancasila character values. The analysis also shows that one of the subjects that can be integrated with this character's values is the work and energy subjects. In this stage, core competencies, basic competencies, indicators of competency achievement, and learning objectives are formulated according to the 2013 revised 2017 curriculum.

\subsection{Design Stage}

Several results obtained in this stage including guidelines for developing e-modules, flowcharts, storyboards, and the initial design of e- modules. An emodule development guideline, flowchart, and storyboard are made as a guide for e-module development. The e-module is then created with the help of kodular, which is a website that provides tools for creating Android applications using block programming. work and energy subjects, 2) the sub material presented is work, energy, work relations and energy, and the law of conservation of mechanical energy, 3) Pancasila character values are integrated into the presentation of material, sample questions, and other test questions on emodules, and 4) e-modules are operated via a smartphone with a minimum Android version 4.0.

The e-module has several components including 1) the front page, 2) the e-module menu, 3) the introduction which contains an introduction, learning instructions, competencies, and concept maps, 4) three learning activities, each of which contains an apperception video, the "let's go exploration of your knowledge ", "let's investigate", and "let's evaluate", 5) summaries, 6) formative tests, 7) answer keys, 8) references, and 9) developer profiles. The Pancasila character values integrated into the e-module include the values of hard work, discipline, responsibility, never give up, cooperation, independent, religious, tolerance, social care, anti-discrimination, environmental care, love the motherland, honest, love the truth, anti-corruption, fair, respect and respect each other, national spirit, anti-bully and violence, nationalist, democratic, peace-loving, friendship, willing to sacrifice, and resilient. These values are extracted from work and energy materials and integrated into e-modules through the analogy of life and exemplary examples of Pancasila practice. This integration is carried out on the material, example questions, practice questions, and evaluation questions on the e-module.

\subsection{Develop Stage}

The e-module products obtained at the design stage are first validated by experts, physics teachers, and peer reviewers and are tested on students. This was done to obtain improvement materials so as to obtain the final product of the integrated physics learning e-module with Pancasila character values in work and energy subject. Validation results, input/suggestions for improvements obtained at the validation stage, and student response results obtained from the product trial phase are explained as follows.

Table 3. The results of the validation/ assessment of the feasibility of the physics learning e-module product integrated with Pancasila character values in work and energy subjects by material experts, media experts, physics teachers, and peer reviewers.

\begin{tabular}{|l|l|c|c|}
\hline \multicolumn{1}{|c|}{ Aspect } & \multicolumn{1}{|c|}{ Components of Assessment } & Average Score & Category \\
\hline \multirow{2}{*}{ Material } & Content Feasibility & 3.90 & Very Good \\
\cline { 2 - 4 } & Language and Image & 3.83 & Very Good \\
\hline \multirow{3}{*}{ Media } & Presentation & 3.65 & Very Good \\
\cline { 2 - 4 } & Graphics & 3.77 & Very Good \\
\cline { 2 - 4 } & Audio & 3.72 & Very Good \\
\hline
\end{tabular}

The initial design of the developed e-module has several characteristics, including 1) the material presented is 
3.3.1. The Validation/ Assessment of The Feasibility of The Integrated Physics Learning EModule with Pancasila Character Values in Work and Energy Subjects.

Validation/ assessment of product feasibility is carried out by material experts, media experts, physics teachers, and peer reviewers of the material and media aspects. The assessment of the material includes two components of assessment, namely 1) content feasibility and 2) language and images, while the assessment of the media includes three components of the assessment, namely 1) presentation, 2) graphics, and 3) audio. The results of the validation/assessment of the feasibility of of assessment, namely 1) material, 2) readability of language and images, 3) presentation, 4) module display, 5 ) audio, and 6) usage. The results of students' responses to the developed e-modules are presented in Table 4.

The results of student responses showed that the six aspects of the assessment obtained an average score above 3.40. These six aspects were evaluated in the "Very Good" category. Students also respond well to e-modules that are developed. Generally, there are no errors and criticisms from students. Based on these results and the results of previous studies [14], [19], the integrated physics learning e-module with Pancasila character values in work and energy subjects was declared feasible and received positive responses for use in learning.

Table 4. The results of students' responses to the integrated physics learning e-module with Pancasila characters values in work and energy subjects.

\begin{tabular}{|l|c|c|}
\hline \multicolumn{1}{|c|}{ Aspects of Assessment } & Average Score & Category \\
\hline Material & 3.43 & Very Good \\
\hline Readability of Language and Image & 3.41 & Very Good \\
\hline Presentation & 3.43 & Very Good \\
\hline Module Display & 3.41 & Very Good \\
\hline Audio & 3.47 & Very Good \\
\hline Usage & 3.41 & Very Good \\
\hline
\end{tabular}

the integrated physics learning e-module with Pancasila character values on the subject of effort and energy are presented in Table 3.

The validation/ product feasibility assessment results show that the five components of assessment obtained an average score of more than 3.50 . However, comments or suggestions for improvement were also obtained, among others 1) improvements about the concept of vectors, equations involving vectors, giving the direction of motion to the image, 2) the use of conjunctions at the beginning of a sentence needs to be improved, 3 ) writing the formula of right and left segments must be the same magnitude, 4) the source of the image must be completed, and 5) the information on the concept map needs to be added.

The validation results also show that the five components of an assessment are included in the "Very Good" category. Based on the results of the validation/ product feasibility assessment and the results of previous studies [22],[25], the integrated physics learning emodule with Pancasila character values in work and energy subject was declared feasible for use in learning.

\subsubsection{Student Responses to The Integrated Physics Learning E-Module with Pancasila Character Values in Work and Energy Subjects.}

E-module products that have been improved based on validation results are then tested. Trials were conducted to obtain student responses in the form of assessments, criticisms, and suggestions for e-modules that were developed. Student responses were given to six aspects

\section{CONCLUSION}

Based on the results of research and development, it can be concluded that has been produced an integrated physics learning e-module with Pancasila character values in work and energy subject that are feasible for use in learning. The e-module that was developed obtained an assessment that included in the "Very Good" category on the five components of the assessment based on the assessment of material experts, media experts, physics teachers, and peer reviewers. The developed e-module also received positive responses from students. The response is given through an assessment of six aspects of the assessment. The results show that all six aspects of the assessment are included in the "Very Good" category.

\section{REFERENCES}

[1] Ozdamli, F, Attitude and opinions of special education candidate teacher regarding digital technology, in: World journal on educational technology: Current issues vol. 09 (4), 2019, pp. 191. DOI: https://doi.org/10.18844/wjet.v9i4.2581

[2] Kristiawan, M, A Model for Upgrading Teachers' Competence on Operating Computer as Assistant of Instruction, in: Global Journal of Human-Sosial Science: G Linguistics \& Education, vol. 14 (5), 2014, pp. 45.4 DOI: https://doi.org/10.31219/osf.io/m6wgn

[3] Wiana, W., Syaom Barliana, M., \& Riyanto, A. A, The effectiveness of using interactive multimedia based on motion graphic in concept mastering 
enhancement and fashion designing skill in digital format, in: International Journal of Emerging Technologies in Learning, vol. 13(2), 2018, pp. 5. DOI: https://doi.org/10.3991/ijet.v13i02.7830

[4] Yulando, S., Sutopo, S., \& Franklin Chi, T, Electronic Module Design and Development: An Interactive Learning, in: American Journal of Educational Research, vol. 7(10), 2019, pp. 695. DOI: https://doi.org/10.12691/education-7-10-4

[5] Lee, S. M., \& Trimi, S, Innovation for creating a smart future, in: Journal of Innovation and Knowledge, vol. 3(1), 2018, pp. 1. DOI: https://doi.org/10.1016/j.jik.2016.11.001

[6] Subroto, G, The Role and Challenges of ICT (Internet) in Development of Education Indonesia, in: Jurnal Teknodik, vol. 19(2), 2015, pp. 124. DOI: http://dx.doi.org/10.32550/teknodik.v20i2.240

[7] Mason, R, Open and Distance Learning Series. Using Communications Media In Open and Flexible Learning, London, Kogan Page, 1994.

[8] Saud, Inovasi Pendidikan, Bandung, Alfabeta, 2011.

[9] Arslangilay, A.S, 21st century skills of CEIT teacher candidates and the prominence of these skills in the CEIT undergraduate curriculum, in: Educational Policy Analysis and Strategic Research, vol. 14(3), 2019, pp. 330. DOI: https://doi.org/10.29329/epasr.2019.208.15

[10] Younes, M. B., \& Al-Zoubi, S, The Impact of Technologies on Society: A Review, in: IOSR Journal Of Humanities And Social Science, vol. 20(2), 2015, pp. 82. DOI: https://doi.org/10.6084/m9.figshare.1353160.v1

[11] Nazarlou, M. M, Research on Negative Effect on ELearning, in: International Journal of Mobile Network Communications \& Telematics, vol. 3(2), 2013, pp. 13-15. DOI: https://doi.org/10.5121/ijmnct.2013.3202

[12] Stalans, L. J., \& Finn, M. A, Understanding How the Internet Facilitates Crime and Deviance, in: Victims and Offenders An International Journal of Evidence-Based Research, Policy, and Practice, vol. 11(4), 2016, pp. 501-502. DOI: https://doi.org/10.1080/15564886.2016.1211404

[13] Kristiawan, M, A Model of Educational Character in High School Al-Istiqamah Simpang Empat, West Pasaman, West Sumatera, in: Academic Research Publishing Group, vol. 1(2), 2015, pp. 15-20. DOI: https://doi.org/10.31219/osf.io/2q3we

[14] Albantani, A. M., \& Madkur, A, Integrating charatcer education values in language teaching: why and how? In: The 4th ELITE International Conference, 2016, pp. 400-402.

[15] Malihah, E, An ideal Indonesian in an increasingly competitive world: Personal character and values required to realise a projected 2045 'Golden Indonesia, in: Citizenship, Social and Economics Education, vol. 14(2), 2015, pp. 1-4. DOI: https://doi.org/10.1177/2047173415597143

[16] Wijaya, E. Y., Sudjimat, D. A., \& Nyoto, A, Transformasi Pendidikan Abad 21 Sebagai Tuntutan Pengembangan Sumber Daya Manusia Di Era Global, in: Prosiding Seminar Nasional Pendidikan Matematika, 2016, pp. 263.

[17] Suherman, A., Supriyadi, T., \& Cukarso, S. H. I, Strengthening national character education through physical education: An action research in Indonesia, in: International Journal of Learning, Teaching and Educational Research, vol. 18(11), 2019, pp. 126. DOI: https://doi.org/10.26803/ijlter.18.11.8

[18] Ramadoni, A., Yulkifli, \& Ratnawulan, Development of physics module SMA/MA integrated character values based on discovery learning models with approach science process skills, in Journal of Physics: Conference Series, vol. 1185(1), 2019, pp. 1. DOI: https://doi.org/10.1088/1742-6596/1185/1/012068

[19] Hadi, R, The Integration of Character Values in the Teaching of Economics: A Case of Selected High Schools in Banjarmasin, in: International Education Studies, vol. 8(7), 2015, pp. 11. DOI: https://doi.org/10.5539/ies.v8n7p11

[20] Suprapti, E., \& Mursyida, H, Pengembangan Modul Pembelajaran Aljabar Linier dengan Tahapan 4ME untuk Pengembangan Karakter 4C'S Mahasiswa, in: Journal of Mathematics Education, Science and Technology, vol. 2(2), 2017, pp. 209. DOI: http://dx.doi.org/10.30651/must.v2i2.841

[21] Perdana, F. A., Sarwanto, S., Sukarmin, S., \& Sujadi, I, Development of e-module combining science process skills and dynamics motion material to increasing critical thinking skills and improve student learning motivation senior high school, in: International Journal of Science and Applied Science: Conference Series, vol. 1(1), 2017, pp. 45. DOI: https://doi.org/10.20961/ijsascs.v1i1.5112

[22] Ridwan, Adnan, \& Bahri, A, Pengembangan EModul Biologi Berbasis Nilai Iman dan Taqwa pada Siswa MA Kelas XI E-Modul Development Based on The Value of Faith and Taqwa in Student MA Grade XI, in: Prosiding Seminar Nasional Biologi Dan Pembelajarannya, 2018, pp. 419. 
[23] Utami, I. R., Triwoelandari, R., \& Nawawi, M. K, Pengaruh Modul Pembelajaran IPA Terintegrasi Nilai Agama Terhadap Pengembangan Karakter Mandiri Siswa, in: Jurnal Pendidikan Dasar Nusantara, vol. 5(1), 2019, pp. 59. DOI: https://doi.org/10.29407/jpdn.v5i1.13036

[24] Widoyoko, E, Evaluasi program pembelajaran: Panduan praktis bagi pendidik dan calon pendidik, Yogyakarta, Pustaka Pelajar, 2009.

[25] Miftahuddin, M., \& Kuncorowati, P. W, Pengembangan modul pendidikan karakter kebangsaan Pancasila di sekolah menengah pertama berbasis pesantren, in: Jurnal Civics: Media Kajian Kewarganegaraan, vol. 15(2), 2018, pp. 134. DOI: https://doi.org/10.21831/jc.v15i2.20134 